\title{
Myles Brand and the Responsibility of Leadership
}

\author{
Walter Harrison \\ University of Hartford
}

\section{Introduction}

For twelve years I have kept a picture of Myles Brand and me on my desk. In the picture Myles and I stand, facing each other with very serious faces in a hallway of a convention hotel in a major American city. Myles is telling me something, and I am listening intently. We are both wearing coats and ties, as we always did during National Collegiate Athletic Association (NCAA) meetings, and we must be on a break from an important committee meeting. I don't remember what city or hotel it was, what committee or board meeting we were taking a break from, or what pressing matter we were both so much involved with. But I love this picture because it reflects the passion, the seriousness, and importance of the work we were doing together in leading the NCAA governance process. The picture first appeared in a celebratory booklet the NCAA published in 2009, just after Myles's death. I asked for a copy of it, and have cherished it ever since.

I would like to think that we were talking during a break in a Committee on Academic Performance meeting. I chaired that committee between 2004 and 2014, and leading that committee and working hand in hand with Myles on what came to be known as academic reform in the NCAA are two of my fondest accomplishments during my 45-year career in higher education. At Myles's suggestion, I also served as chair of the Executive Committee between 2005-2007 and the Presidential Advisory Group during the same time. These three positions, in addition to my service on the Division I Board of Directors between 2002-2007, gave me a wonderful perspective to watch Myles's leadership of the NCAA.

Myles was a leader who thought at great length about the most important challenges facing intercollegiate athletics, gathering as much data and as many opinions as possible, then formulating and eloquently expressing his plans for overcoming those challenges, putting them in motion, keeping in touch with the key people who were leading those efforts, and then holding himself and the NCAA accountable for the results and announcing those results in a public and transparent manner. As a result, his presidency marked, in my estimation, the high point in the NCAA's history. 
In this paper, I intend to discuss Myles's leadership in two areas-academic reform and fiscal sustainability - where I was intimately involved.

I was elected by my colleagues in the America East Conference to join the NCAA Division I Board of Directors in 2002 and attended my first board meeting in August of that year. I learned during that meeting that a working group of presidents had formed to study how to make data-driven decisions that would lead to an improvement in student-athletes' academic experience. I joined the group immediately. I also learned that the search committee was narrowing the list of candidates for the NCAA presidency. So I was not surprised during the second meeting of the Division I Board I attended in October to learn that Myles had been selected. I only knew Myles by reputation, especially because he had fired Indiana University's well-known head men's basketball coach, Bob Knight, for his treatment of student-athletes. Myles came to our meeting briefly and made a few comments, and we all introduced ourselves.

We all first learned about Myles's initial plans for his presidency during his speech to the NCAA Convention in January 2003. He had only been on the job for two weeks when he gave that speech, but all of us who heard it realized immediately that Myles was well-versed in the challenges facing intercollegiate athletics and had absorbed a great deal of information about them in the three months since he had been elected to the presidency. It was also clear that Myles was prepared to roll up his sleeves and take on these challenges personally; he was prepared to be a hands-on president. I for one found that refreshing.

In that speech, Myles outlined two overarching themes that would become the cornerstones of his presidency: the imperative to provide better academic experiences for all athletes and to improve their graduation rates, especially in football and men's basketball; and the need to address the financial challenges that universities faced, especially with the budgetary growth associated with athletics. He clearly stated that the Association should confront the need for both reform and advocacy: reform those areas that required it but advocate for "the positive value of intercollegiate athletics, to advocate for the benefits intercollegiate athletics provide young women and men and the colleges and universities they attend" (Brand 2003, p. 2). These subjects - academics and financial reform - and these approaches-reform and advocacy — would become recurrent themes throughout Myles's tenure.

Myles also struck the tone that would characterize his tenure: a direct style but a focus on the overarching values that should inform everything the NCAA does. For example, in issuing his call for reform and advocacy, he said:

We must be clear that reform and advocacy are not merely compatible, they are mutually supporting. We must undertake both, and we must do so simultaneously. Without genuine reform, the future of intercollegiate athletics is in peril. Without vigorous advocacy, the value of intercollegiate athletics will be unrealized (Brand, 2003, p. 2).

He clearly and concisely advocated for ethical behavior, something one might have expected from a philosopher like Myles, but one that was welcomed nonetheless: 
Fairness and ethical behavior are required - not merely preferred - in intercollegiate athletics. That pertains, for example, to the way coaches treat student-athletes, the way student-athletes treat each other, to the way universities deal with student-athletes, and to the way the NCAA interacts with everyone (Brand, 2003, p. 6).

\section{Academic Reform}

In this first speech to the Association, Myles outlined in some detail the need to improve student-athletes' academic success. This was no surprise; the NCAA Division I Board had been studying these matters for a year or so before Myles took office. They had not, however, reached the point where a real reform program had begun to emerge, but Myles described the desire to have incentives and disincentives to motivate universities to provide the support necessary for student-athletes to succeed academically. He spent almost as much time describing the need to come to grips with the runaway spending in college athletics, and began to formulate one of his most memorable and unexpected positions: that commercialism can be good for college sports as long as their integrity is not compromised. This was somewhat surprising, since Myles had been a president of two leading research universities, and the expectation was that with that background he might shy away from commercial support of college sports. Although he admitted that he could not define "ironclad, specific criteria for judging when commercial interests overwhelm college sports," he was clear that if handled correctly corporate and commercial support of college sports could improve the experience of student-athletes (Brand, 2003, p. 6).

The final striking aspect of Myles's first speech to the NCAA community is his insistence that the Association develop strategic plans for both academic reform and meeting financial challenges. Within 18 months he would lead the Division I Board in creating a permanent committee to oversee improved academic performance of student-athletes. It would take about two years for him to create a Task Force on the Future of Division I Intercollegiate Athletics. But in that first address he told the Association that both efforts were coming.

Since the Division I Board had an active group of us thinking about how to measure and assess the academic progress of student-athletes, Myles had an active, knowledgeable, and attentive group of presidents to work with. He also discovered that he had a very talented and dedicated group of NCAA senior staff members to call on to help guide and support the effort. David Berst, the vice president of Division I governance aided in guiding the board, and Myles called upon Kevin Lennon, vice president for academic and membership services, and Diane Dickman, managing director of academic and membership services, to lead the effort in academic progress. He could not have found three better or more knowledgeable leaders. All three had played Division I sports (Berst and Lennon — baseball; Dickman — golf), and all three had experience in NCAA affairs. In addition, the NCAA had a very talented data and research staff, led by Todd Petr and soon to be joined by Tom Paskus, who at that time was a consultant to the Board's academic working group. Finally, in 
Wally Renfro Myles had found the perfect special assistant for public affairs, both to help him refine his thinking not only about academic progress but also about the role of the NCAA in governing college sports. Even for those of us who worked closely with Myles, it was very difficult to discern where Myles's thinking started and where Wally's ended.

By the summer of 2003, the Board's working group had outlined the most important goals of the academic progress effort: to improve student-athlete academic success and graduation rates in measurable and assessable ways, and to develop incentives and disincentives for colleges and universities to help make progress possible. That working group had also decided that all decisions needed to be based on reliable and accurate data. As I look back on this period, these goals and methods seem self-evident, but it took a lot of leadership and hard work to get to these conclusions. Three university presidents were especially helpful in leading this effort: John Casteen of the University of Virginia; Francis Lawrence of Rutgers; and Robert Kennedy of the University of Kansas.

But Myles realized that he needed more help from respected and thoughtful leaders of athletic departments, so he led the Board to establish an Incentives and Disincentives Working Group to think carefully about incentives and disincentives for athletic departments in Division I. With the help of Lennon, Dickman, and Petr, this group of experienced athletics directors, administrators, and faculty athletics representatives outlined a pathway: measurable year-by-year metrics, and disincentives that would range from loss of athletic scholarship opportunities to ineligibility for national championships. They struggled with appropriate incentives, and these would not be finally established until 2016, long after Myles had died and I was no longer involved directly in the effort. But enough had been done to begin earnest work on establishing an academic performance program.

While that working group was meeting regularly, Myles led the Division I Board in establishing a standing committee to develop the specifics of the program. Myles was clear that this was the most important work ahead of the Association in the years ahead, and the Board discussions led to a decision to have that Board chaired by a sitting president, who was directly accountable to the Board itself. Nominations were sought nationally for this position, and during one Board discussion of the importance of a president leading the effort and reporting to the Board, Mary Sue Coleman turned toward me and said, "Why not you?" To this day, I do not know if that comment was the result of a nomination, a decision prompted by Myles, or simply a spontaneous suggestion by Mary Sue.

At any rate, my appointment was confirmed by the Board and in the summer of 2004 I took on what was to become a 10-year chairmanship of the Committee on Academic Performance (CAP). I was sent to be debriefed by the incentives and disincentives working group, and I found that they had done an immense amount of thinking about the problem, and developed some important metrics and disincentives, and had identified a group of problems yet to be solved. Lennon and Dickman went to work on developing committee membership, made up of athletic directors and other senior athletic staff, faculty representatives, and senior conference administrators. 
We also identified at least one other president or provost to serve as vice chair. Over the years, those people would be term-limited and replaced by others; I can say that, in every case, all of the committee members were knowledgeable, thoughtful, and diligent; everyone kept the common good and the welfare of student-athletes front and center in their thinking about these issues. I especially want to cite three very important thought leaders of this group throughout the decade I served as chair: Jack Evans, faculty athletic representative and professor of business administration at the University of North Carolina, Chapel Hill, was the resident expert on data and statistical measurement (he served on the incentives and disincentives working group before CAP was formed and, therefore had an historical understanding of how measurements were developed); Greg Sankey, who was then associate commissioner of the Southeast Conference but had also been commissioner of a smaller conference, the Southland Conference and, therefore, understood the concerns of both major and mid-major conferences; and John Morris, associate athletic director at the University of Washington and later senior associate athletic director at Colorado State University, whose experience in athletic compliance was invaluable in thinking about how universities would administer the program on their campuses.

When we started our work as a committee, the task seemed daunting: develop a program from scratch that would be so widely known and transparent throughout Division I that it could dramatically increase student-athlete academic performance and graduation rates; make that program both measurable and meaningful; and track the performance of all student-athletes who were receiving athletic scholarships in Division I. Aided by Lennon and Dickman's understanding of the Division I landscape and Petr and Paskus's knowledge of statistical data, we developed a transparent program based on two chief indices: eligibility and retention. We also developed the notion of measuring these every term (semester or quarter - and the "translation" of quarterly grades to semester grades itself was a hotly debated point for over a year). The unit of measurement would be the team - not the athletic department (this was also a debatable point) — since sports make different demands on athletes depending on their length of season (basketball and ice hockey, for example span either two semesters or quarters, while most other sports have shorter seasons that line up better with single terms).

Within two years we had developed the basic program, known as the Academic Performance Program. Each athlete could earn two points each term-one for remaining academically eligible (eligibility), and one for remaining on the team (retention). These would be tallied each term but calculated formally each academic year. The percentage of possible points each team earned would determine their Academic Performance Rate (APR). But thinking that percentages would be complicated to explain, we decided to use three digits to stand for the rate (earning $92.5 \%$ of the points a team could have earned would give them an APR of 925, for instance). As the least statistically adept person on the committee, I thought of this system like a batting average in baseball. If you got a hit three of every 10 times you were up, you had a .300 batting average, not a $30 \%$ average. 
If one counted the same points over a four-year period, one derived a Graduation Success Rate (GSR), which could measure how effectively that team's students were progressing to graduation. As early as the late 1990's the Knight Commission had called for at least a $50 \%$ graduation rate in order for teams to be eligible for postseason play. Petr and Paskus and their team were able to correlate a $60 \%$ graduation rate to a $925 \mathrm{APR}$, and so we had two rates that could effectively measure academic progress toward degree (APR) and graduation rate (GSR, Graduation Success Rate).

Capturing how all this works in a three-paragraph summary significantly obscures how difficult it was to arrive at these rates. It took a great deal of work by the committee, a great deal of prodding by Myles amid a great deal of skepticism by both critics of the NCAA and by the media, and an enormous amount of fact-gathering by the NCAA staff over 18 months of hard work, but we came together as a committee and a Board in good faith and common trust in the power of data to drive decision making. I reported to the Board on our progress and our stumbling blocks at each Board meeting, and Myles and I would meet with media representatives after each meeting to report on our progress. I also reported to the Knight Commission once a year on our progress in a public meeting. The questions and criticism of those groups helped immensely in both refining the system and clarifying the language we used to define it.

In addition to these formal reports to governance groups and the media sessions, the NCAA staff traveled extensively to Division I conference meetings and to regional gatherings of specific groups like academic advisors, coaches groups in most sports, and athletic administrators. Frequently they would bring back criticisms and concerns they had heard, and we considered them carefully during our meetings.

Myles also met with the national coaches groups, especially in football and basketball, and he kept them informed and also brought back their concerns to the NCAA staff and the committee. I traveled with him on two occasions to meetings with the National Association of Basketball Coaches (NABC), the group that represented men's basketball coaches. In many ways, this was the most critical group. They began by being very skeptical, but thanks to Myles's straightforward effort to enlist their help and support, they came around over time to be supportive of our efforts.

It wasn't always easy. In the last year of Myles's life, when he was battling pancreatic cancer, I went in his place to an NABC meeting during the NCAA Final Four to explain the "coaches' scorecard" we had developed to reflect how well teams under each head coach had performed academically. Presidents, who were involved in most cases with athletics directors in choosing head men's basketball coaches, wanted such a scorecard to measure against a won-lost record, which had been the only real measure up to that time of coaching success. Several of the coaches present were very loudly critical of this effort, and told me so directly and strongly. After my presentation and the questions by the coaches, as I was leaving the meeting, the NABC leaders made a point of telling me that they continued to support our efforts, and that individual coaches were just expressing surprise and skepticism of change. 
During the period the committee, which met quarterly in person and frequently by phone between in-person meetings, was developing the metrics and the program, Myles met with us at least three times each year. He inspired us, he prodded us when necessary, and he critiqued and praised our work as needed. It was clear to him, to me, and to the committee that he had tied his own reputation and legacy to the work of the committee. With Myles's support and encouragement, we worked diligently to make sure we had a program that was statistically accurate, was easily measurable, and which was transparent enough that everyone involved - student-athletes, coaches, athletic departments, presidents, boards of trustees, the media, and the general public - understood when student-athletes had succeeded and when their universities had failed them.

By the summer of 2006 - two years into our work-Myles was able to report the immediate and early success of our program. In a speech to the National Press Club in October, 2006, Myles was able to announce "significant progress in academic reform" (Brand, 2006a, p. 1):

When I initially talked about academics first five years ago [referring to a speech he made to the same group in 2001, as president of Indiana University], the graduation rate of student-athletes in Division I was 58 percentthree percentage points better than the student body. Football players were graduating at a rate of 49 percent and male basketball players at a rate of 40 percent.

Five years later, student-athletes are graduating at a rate of 63 percent - five points better than five years ago.

That $i$ significant progress. Anyone knowledgeable about graduation rates knows that, for a large population of students, an increase of five percentage points, plus upward trends in all demographic categories, is genuine and significant progress.

Football student-athletes increased five points to 54 percent in those five years. Male basketball student-athletes likewise gained five points from 40 to 45 percent. (Brand, 2006a, p. 2).

During our deliberations as a committee, we confirmed what many other observers of higher education had commented on in the past: the federal government's method of counting graduation rates in higher education was demonstrably flawed. It only counts first-time, first year students. Someone who transfers out of a university or college is considered not to have graduated. Someone who transfers in is never counted. In creating the GSR of student-athletes, Myles and I both believed, we had created a model that better reflected student behavior and tracked them to graduation, whether they transferred in or out. Myles tried, without success, to convince the U.S. Department of Education to revise the way it counted graduation rates. To this date, the federal graduation has not been changed to more accurately reflect student behavior.

Using the newly defined GSR, Myles was able to tell the audience at the National Press Club that the actual graduate rate of student-athletes in Division I was 
“77 percent - up one percentage point from a year ago, and 14 points more accurate than the federal rate" (Brand, 2006a, p. 3). He would later challenge Division I universities and colleges - and the student-athletes - to achieve an 80 percent GSR, something they accomplished before he died.

\section{Myles and NCAA Governance}

In the spring of 2005, Myles and Carol Cartwright, who was president of Kent State University and was serving as chair of the NCAA's executive committee, the governance group that oversaw all three divisions of the NCAA and was made up of leaders from each of them, approached me about succeeding Carol in summer of that year. I was surprised to be asked, but deeply flattered. I knew that no president of an institution that did not play football in the Football Bowl Subdivision (FBS), the universities and colleges that offered 85 full scholarships in football, had ever served as chair of the executive committee. I had served on the executive committee for a year and a half, and I knew how it functioned, and I believed I could help in that role. So I accepted.

A few months later Myles called me to discuss one of the trickiest governance subjects: how to satisfy presidents of the non-FBS conferences who were not represented on the Division I Board. Just a short explanation of this problem. Division I spans approximately 350 different colleges and universities who differ in size, in funding, in mission, and in endowment. The 11 conferences that offer FBS football had permanent seats on the Division I Board, which had at that time 18 total seats. The remaining seven seats were rotated among the 20 other conferences (now 21) in Division I. As a result, 13 conferences were unrepresented at any one time, and those conferences felt disconnected from the decisions that NCAA governance was making. Myles and David Berst thought they might form a group, which they wished to call the Presidents' Advisory Group (PAG), to represent those 13 conferences, and that all 20 non-FBS conferences would be asked to send a representative to those meetings. They wanted to know what I thought of that organizational concept. I thought it was worth a try, and we jointly decided that the PAG (the NCAA has acronyms for everything) could meet the day before the Division I Board and discuss the issues that would come before the Board the next day. Then they surprised me by asking if I would chair that group.

The upshot of all this was that from 2005-2007 I was chairing three important groups in NCAA governance: the executive committee, the PAG, and the CAP. Those three positions gave me an excellent perspective on the entire NCAA during those years, and an equally great perspective on Myles' leadership style.

During that time Myles invited me to join him at dinner on the night before all three of the groups would meet - sometimes just the two of us, sometimes with his wife, Peg, and sometimes with another president, frequently the chair of the Division I Board. Some of those meetings were entirely friendly discussions, but some involved very intimate and detailed discussions of the most significant problems facing the NCAA: strategic priorities, important lawsuits, important contract negotiations 
with corporate partners, problems in governance or even with senior staffing at the NCAA, and sometimes with the complex and tricky politics involved in keeping the entire 1200-member association moving in the right direction.

\section{Fiscal Responsibility}

Many of those dinner conversations initially involved academic reform, but as that area began to show real progress, Myles frequently turned to the other major strategic initiative he had outlined to the National Press Club audience in 2006: institutional accountability for responsible fiscal management. Myles realized from the beginning that this subject posed significantly more complex issues than academic reform. He realized they had two aspects in common: that the future public confidence in the NCAA depended on its being able to manage change in both areas, and the "bully pulpit," the moral persuasive power of the NCAA president. But they also differed dramatically: where institutional presidents were united in their beliefs that the NCAA could provide a unified approach to improvement in the academic performance of student-athletes, they were not willing to allow the NCAA to "control" fiscal performance of either athletic departments or universities or colleges. Those problems lay within the responsibilities of presidents and institutional governing boards.

What he led me, and sometimes Peg or other presidents, to ponder was whether the "moral suasion" (his term) of his position was strong enough to persuade presidents and institutions to do the right thing in providing fiscal responsibility and to improve student-athlete welfare. In 2004, Myles and Michael Adams, who was president of the University of Georgia and chair of the finance committee of the executive committee, had made a major recommendation in the direction of greater fiscal responsibility of the NCAA. As the broadcast rights for the NCAA Division I men's basketball tournament had dramatically increased with new contracts, they persuaded the executive committee to hold back some of the distribution of that money to the membership in order to build a "reserve fund" that might be called on to get the NCAA through any unforeseen difficult financial time. At that point, three years or so after the attacks of September 11, 2001, we were focused on terrorism and what affect it might have on a men's basketball tournament in future years. Little did we know that it would be a pandemic that would cause the NCAA to have to look to the reserve fund we had established in order to assure its survival 16 years later.

Myles, his senior executives, I, and the other leaders of NCAA governance knew that if we were to succeed in convincing presidents and governing boards to take fiscal responsibility seriously enough in order to assure the sustainability of intercollegiate athletics, we would need presidents of major universities to lead a task force to examine the issues. Myles was able to recruit Peter Likens, who had been active in NCAA matters and who had recently retired from the presidency of the University of Arizona to chair the task force; Larry Faulkner, president of the University of Texas, to chair the subcommittee on aligning athletics with the values of higher education; Gerald Turner, president of Southern Methodist University, to chair the subcommit- 
tee on the influences of outside constituencies on effective presidential leadership; and Karen Holbrook of The Ohio State University to chair the subcommittee on the well-being of student-athletes.

Eighteen months after the Presidential Task Force met for the first time, it published its report entitled The Second Century Imperatives: Presidential Leadership -Institutional Accountability (Brand, 2006b; Brand, 2006c). Divided into four sections-Fiscal Responsibility, Integration of Athletics into the University Mission, Relationships with Internal and External Constituencies, and Student-Athlete Well-Being - the report contained two dozen different initiatives, some that could be instituted by the NCAA, but most to be instituted by individual campuses.

The Fiscal Responsibility section was the most extensive and hard-hitting. Both Myles and the task force members knew that strong measures needed to be taken, both on national and individual institutional levels, in order to reduce the rapid growth in athletic department budgets. The task force called on the NCAA to establish a financial database that included all aspects of institutional athletics budgets, from scholarships to salaries and benefits to capital budgets. These institutional reports would be reviewed by outside auditors using "agreed-upon procedures" (Brand 2006c, p. 25), then reported to the institutional president or chancellor and then to the NCAA. The task force also called for financial "dashboard indicators" which would allow presidents and athletic directors to compare their institutional budgets with those of their peers (Brand 2006c, pp. 25-26).

The rationale behind these two key recommendations was two-fold: athletic directors often lobbied their presidents for budget increases based on what competitors were spending; and presidents frequently were pressured by boosters, donors, media, and fans to increase salaries and facilities for much the same reasons. If a confidential database could provide accurate information for presidents, this would allow them to have some independent confirmation or rebuttal of these claims.

In 2007 Myles asked a number of presidents - including me - to work on creating this database. Under the direction of NCAA chief financial officer James Isch, we created the database and dashboard indicators. To some extent these financial indicators reflected a compromise between public and private institutions: publics wanted the privates to have to state the scholarship costs, which we knew were higher without the state subsidies that publics receive, but privates wanted publics to have to report the costs of their facilities, which in some public institutions are built and maintained by other state agencies or departments.

The report also called for an accounting of the costs of NCAA regulation, something that would satisfy those members who felt put-upon by NCAA requirements, and it called for regular monitoring by the NCAA Division I Board of the trends of athletics financing across the division. Unfortunately, neither of these practices was ever implemented.

In the section that called for the integration of athletics into the university mission, the report recommended greater oversight of athletics by the faculty, especially citing a growing role for the Faculty Athletics Representative, and recommended that the athletic compliance officer report directly to the president rather than the 
athletic director. It also called for a maximum number of "special admissions" for athletes, something that had grown out of the academic reform movement (Brand 2006c, p. 34.).

In some ways the section that dealt with the relationship of athletics to the governing board was the most sensitive. Myles had reached out to the Association of Governing Boards (AGB), whose president, Richard Legon, worked closely with this subcommittee in emphasizing the AGB's "Statement on Board Responsibilities for Intercollegiate Athletics" (Brand 2006c, p. 43). Here the task force wanted to state clearly that the president had the responsibility for operating the intercollegiate athletics program, and the Board's role should always be in an oversight capacity.

The final section of the report covered student-athlete well-being, and concentrated on defining academic "at risk" student-athletes and providing them with the necessary support and advice in order to succeed (Brand 2006c, p. 51.). In addition, it suggested further review of whether athletic scholarships should be offered on a four-year basis, rather than the widespread norm at the time of one-year awards, reviewed annually, and went so far as to suggest a review of the possibility of granting five years of eligibility to reflect the growing trends of students remaining on campus for five years as undergraduates (Brand 2006c, p. 52). Unfortunately, none of these suggestions ever materialized.

\section{Conclusion}

Why did one of the two initiatives that Myles Brand announced in his first speech to the NCAA membership - academic reform - succeed while the second one-fiscal responsibility-largely fail? Certainly academic reform succeeded because university and college presidents, who had taken over the governance structure of the NCAA just a few years before Myles became NCAA president, supported Myles. They understood the need for better academic support of student-athletes. Academics was also an area in which the NCAA could foster standards and assign disincentives without fear of legal challenges. Finally, Myles could provide the "moral suasion" that could support presidentially led reform and muster the power of the media, who began with some skepticism but came to be powerful backers of improved academic success.

There are three reasons, I suggest, why Myles did not succeed as clearly with his initiative to foster fiscal responsibility in college athletic programs. First and foremost, this was clearly an area, as Myles said in his speech to the National Press Club in 2006, that antitrust considerations made it impossible for the NCAA to restrict salaries or spending in general. Myles and his colleagues on the Presidential Task Force knew they could only provide a clarion call for all university and college presidents to take responsibility for fiscal responsibility on their own campuses.

Second, it was an area where Myles and his colleagues could only make some changes at the national level, realizing that much of what was needed was local initiative by university presidents. Myles saw the 2006 report, The Second Century Imperatives: Presidential Leadership - Institutional Accountability, as a vehicle to 
promote and support this change, but he realized change had to come primarily at the local level. The report itself identified the opposition it would likely run into on individual campuses - from athletic administrators and coaches, from boards of trustees or regents, from alumni and donors, from legislators, and from so-called "booster groups." Had Myles lived longer, had he been able over a period of, say, five more years to continue to provide strong leadership and support of individual presidents and chancellors as they attempted to hold down the "arms race" on individual campuses, things may have been different.

Finally, however, the power began to shift significantly in 2007 away from the NCAA as a national association and toward the individual conferences. Two things happened that year that signaled this change: first, Myles agreed to allow the Football Bowl Championship institutions and conferences to establish a College Football Playoff that lay outside of NCAA control. I remember Myles telling me that he would not stand in the way of that taking place. I knew what a turning point this would be, and so did he. But he said with the clarity that I had come to expect from him: "I can't stand in the way. They will leave the NCAA if I try."

Second, armed with their new understanding that they could act independently of the NCAA, especially in contractual matters, the most financially secure conferences began to sign media deals for football and men's basketball with important national television or cable networks. I remember clearly a day in the spring of 2007 when Jim Delany, commissioner of the Big Ten, with whom I had worked while I was a vice president at the University of Michigan in the 1990's, called me to tell me "as a courtesy" that his conference had signed such a broadcast rights deal with Fox that eventually, he said, would bring \$40 million to each of the conference's universities. I asked if he had talked with Myles. "I told him yesterday," he replied.

This shift doomed any chances of controlling budgets among the best financed conferences. It also began a steady shift in power and influence away from the NCAA as an association and toward the best-known conferences, especially the best-known football conferences. A year after Myles's death, I was one of the people who was a candidate to succeed him. During my interview with the search committee, I was asked to respond to the question of whether the NCAA should provide greater independence to conferences in matters concerning benefits to student-athletes. Within a year of being selected as Myles's successor, Mark Emmert led an Association-wide vote to provide greater autonomy to the five most prosperous football conferences. The movement toward less control by the NCAA had begun.

If we look back now at the years of Myles's leadership, we can appreciate how clearly he saw the challenges facing the NCAA, and how effectively he formed initiatives to combat them. He succeeded where he had the authority to act, but was considerably less successful where he could only call on his influence and "moral suasion." He was, however, the man for the moment, and the NCAA — and college sports - have never been as successful, as influential, or as closely tied to universities' educational mission as they were then. 


\section{References}

Brand, M. (2003). NCAA State of the Association Address, 2003 Convention. https:// mylesbrand.com/wp-content/uploads/2003/01/2003-NCAA-State-of-the-Association.pdf.

Brand, M. (2006a, October 30). Fiscal responsibility: Report of the Presidential Task Force. National Press Club, Washington, D.C. https://mylesbrand.com/wp-content/uploads/2006/01/National-Press-Club-2006.pdf.

Brand, Myles (2006b, October 1). [2-page] executive summary of The second century imperatives: Presidential leadership —institutional accountability. https://mylesbrand.com/wp-content/uploads/2006/01/2006-Presidential-Task-Force-Exec-Summary.pdf.

Brand, Myles (2006c, October 1). [63-page] The second century imperatives: Presidential leadership - institutional accountability. https://mylesbrand.com/ wp-content/uploads/2006/01/2006-The-Second-Century-Imperatives.pdf. 